\title{
Incubation behaviour and care of a nestling by a pair of Black Fantails Rhipidura atra
}

\author{
Richard H. Donaghey ${ }^{1,2}$ \\ 'Environmental Futures Research Institute, Griffith University, Nathan 4111 QLD, Australia \\ ${ }^{2}$ Address for correspondence: 80 Sawards Road, Myalla TAS 7325, Australia \\ Email: ricardo@southernphone.com.au
}

\begin{abstract}
The Black Fantail Rhipidura atra, endemic to the lower montane forests of New Guinea, builds a typical fantail nest. Observations of a nest placed high up in an understorey tree in the Arfak Mountains in Indonesian New Guinea revealed that the male and female of a pair mostly alternated incubation bouts and contributed almost equally to incubation, care of the nestling and nest-defence. Incubation constancy was $\sim 80 \%$. Observations of Black Fantails mobbing potential nest-predators are described.
\end{abstract}

\section{Introduction}

The fantail family (Rhipiduridae) consists of 48 Rhipidura species, the Drongo Fantail (formerly Pygmy Drongo) Chaetorhynchus papuensis of New Guinea and the Silktail Lamprolia victoriae of Fiji (Irestedt et al. 2008; Nyári et al. 2009; Sánchez-González \& Moyle 2011; Winkler et al. 2015; Beehler \& Pratt 2016; Gill \& Donsker 2017). New Guinea is the centre of fantail diversity, with 14 Rhipidura species, eight of which are endemic, and the Drongo Fantail (Boles 2006; Beehler \& Pratt 2016). Six Rhipidura clades have been identified, five of which occur in New Guinea, demonstrating the island's importance in the speciation and radiation of fantails throughout the Pacific islands (Nyári et al. 2009). The Black Fantail $R$. atra is phylogenetically isolated from the six Rhipidura clades and its relationship to them is unresolved (Nyári et al. 2009).

The Black Fantail is a small, aerial-foraging insectivorous passerine that occurs in lower montane forests mainly at $1000-2150 \mathrm{~m}$ above sea-level (asl). Mean weight is $12.6 \mathrm{~g}$ (range 11.7-13.5 g) for males and $10.7 \mathrm{~g}(9.9-11.3 \mathrm{~g}$ ) for females (Frith \& Frith 1993). Two subspecies are recognised. The nominate atra ranges from the Birds' Head Peninsula throughout the mountains of the Central Ranges to the Huon Peninsula (Beehler \& Pratt 2016), and vulpes occurs in the Cyclops Mountains and the Papua New Guinea (PNG) North Coastal Ranges and presumably the Foja and Adelbert Mountains (Pratt 1982; Beehler \& Pratt 2016). The striking sexually dimorphic plumage of the Black Fantail is exceptional among New Guinean fantails. The Black Fantail mostly captures invertebrates aerially like a flycatcher but also 'flycatcher-gleans' (sally-snatching from a substrate) in the understorey and middle forest layers (Croxall 1977). The nest and egg of this species have been described (Harrison \& Frith 1970; Coates 1990) but many facets of its breeding biology are unknown (Coates 1990; Boles 2006). This paper presents new data on the height of the nest above the ground, and incubation behaviour, care of the nestling, and nest-defence by the adults.

\section{Study sites and methods}

Carolyn Donaghey and I stayed at a hut in montane rainforest $1580 \mathrm{~m}$ asl above Kwau village, Arfak Mountains, West Papua Province, Indonesian New Guinea $\left(1^{\circ} 6\right.$ 'S, $133^{\circ} 55^{\prime} \mathrm{E}$ ) from 1 to 16 November 2012. Our focus was robin (Petroicidae) research, but the discovery of a Black Fantail nest enabled me to study incubation and the care of the nestling in this species. The lower montane rainforest found between 650 and $1500 \mathrm{~m}$ in the Arfak Mountains and the climate of nearby lowland Manokwari are described by Donaghey (2015a).

On 3 November 2012, I found a Black Fantail sitting on a nest in an understorey rainforest tree. Four nest-watches were conducted, two in the morning ( 9 and 11 November) and two in the afternoon (11 and 12 November), and incubation rhythm and behaviour were recorded. From $1545 \mathrm{~h}$ to $1600 \mathrm{~h}$ on 13 November, I watched the male and female feed and brood the nestling, which must have hatched during the previous $24 \mathrm{~h}$. Birds attending the nest were observed through a telescope mounted on a tripod, and their on- and off-bouts of incubation were timed to the nearest second with a lap/split stopwatch. Sex of the adults was determined from the plumage: the male is black and has white eyebrows, and the female has rufous underparts and head, brown wings and a rufous tail with two pairs of black central rectrices. The height of the nest above ground was measured with a bush pole and tape measure. The nest-site and egg of a second pair of Black Fantails are also described.

\section{Observations}

\section{Nest, egg and clutch-size}

The Black Fantail nest in the Arfak Mountains was a typical cup-shaped fantail nest with a 'tail' composed of fibrous plant fragments and bound with copious whitish spider web as described by Harrison \& Frith (1970). It was placed on a thin fork of a horizontal branch in the outer foliage $1 \mathrm{~m}$ from the trunk and $1.5 \mathrm{~m}$ below the top of a densely foliaged middle-storey tree $14 \mathrm{~m}$ high (Figures 1-2). It was situated $12.5 \mathrm{~m}$ above ground and contained one egg.

A second Black Fantail nest, found at Efogi, Owen Stanley Range, Central Province, PNG, on 26 November 1967 , with the female sitting, was $6 \mathrm{~m}$ above ground on an almost horizontal thin branch of an understorey tree. The single egg was cream with brownish blotches at the larger end. 


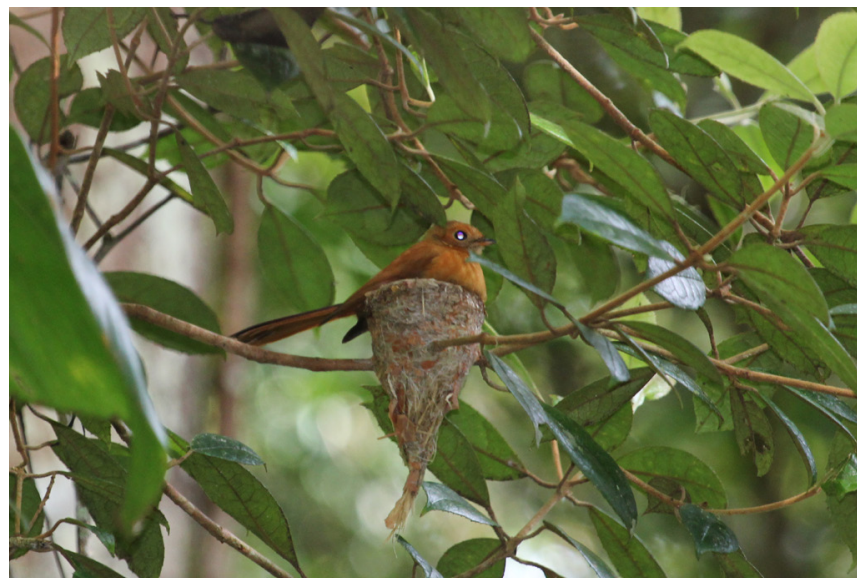

Figure 1. Female Black Fantail sitting on nest, Arfak Mountains, West Papua, Indonesian New Guinea. Photo: Richard H. Donaghey

\section{Incubation behaviour and care of a nestling}

Both the male and the female Black Fantails at the nest in the Arfak Mountains shared incubation. During a 66-minute watch from $1055 \mathrm{~h}$ to $1201 \mathrm{~h}$ on 9 November, nest attentiveness was 50.2 minutes and incubation constancy was $76.1 \%$. On 11 November, during a 132-minute morning watch from $0800 \mathrm{~h}$ to $1012 \mathrm{~h}$ and a 2-h afternoon watch from $1200 \mathrm{~h}$ to $1400 \mathrm{~h}$, nest attentiveness and incubation constancy were 108.38 minutes and $82.1 \%$, and 94.15 minutes and $78.5 \%$, respectively. During a 1-h watch from $1400 \mathrm{~h}$ to $1500 \mathrm{~h}$ terminated by steady rain on 12 November, nest attentiveness was 48.82 minutes and incubation constancy was $81.4 \%$. For all four nest-watches combined, during late incubation, incubation constancy was $79.8 \%$. The total number of incubation sessions was 30 in 378 minutes and was extrapolated to be 57 for a 12-h day. The contribution to incubation by the male was $51.8 \%$ and by the female was $48.2 \%$. Mean duration of incubation sessions by the female was 9.01 minutes (range $0.25-27.37$ min., $n=16$ ) and by the male was 11.15 minutes (0.67-36.48 min., $n=14)$. Both male and female mostly took turns in incubating, except for three times when the female incubated for $<2$ minutes, was absent for $<1$ minute and then resumed incubating. Once, the male incubated for 40 seconds, was off the nest for 20 seconds, then resumed incubating for 4.23 minutes. Mean duration of 29 absences from the nest was 2.64 minutes (range 0.13-17.05 min.). Both male and female engaged in nestdefence during the longest absence.

The nestling hatched between $1500 \mathrm{~h}$ on 12 November and $1530 \mathrm{~h}$ on 13 November. During the 30-minute photographic sessions on 13 and 15 November, both the male and the female fed and brooded the nestling almost equally.

\section{Predator avoidance and nest-defence}

Both the male and the female Black Fantails mostly approached the nest by flying low into the inner foliage of the nest-tree and then ascended to the nest by short flights to inner branches close to the trunk and then along the nestbranch. Once, the male flew directly to the nest. At $0939 \mathrm{~h}$ on 11 November, the sitting male flew $60 \mathrm{~m}$ and joined the female mobbing a Black-eared Catbird Ailuroedus melanotis (Ptilonorhynchidae), a potential nest-predator,

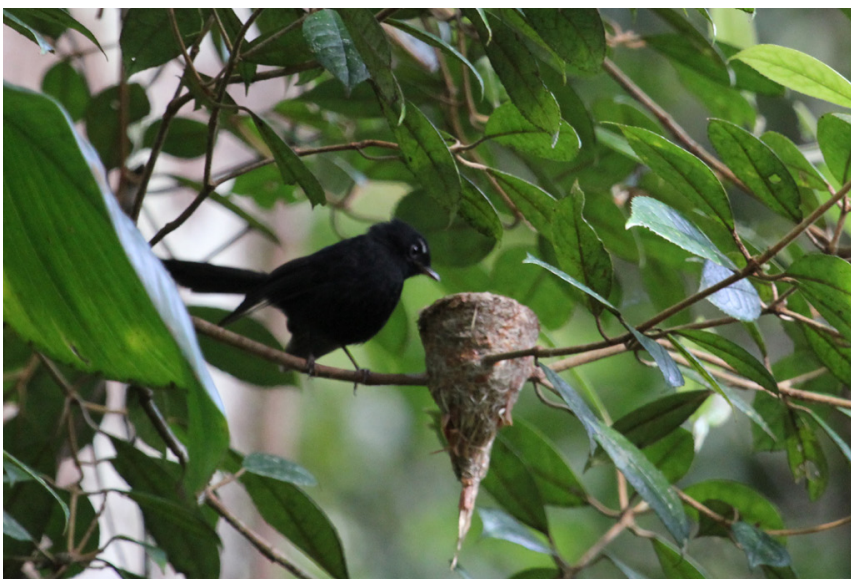

Figure 2. Male Black Fantail at nest high up in densely foliaged tree, Arfak Mountains, West Papua, Indonesian New Guinea. Photo: Richard H. Donaghey

which was foraging 15-20 m up in the canopy and 60-70 m from the Fantail nest. Both male and female Fantails emitted metallic double-squeak alarm-calls as they darted toward and around the Catbird. The Fantail alarm-calls persisted for 11 minutes. At $0956 \mathrm{~h}$, after the Fantail nest had been unattended for 17.05 minutes, the female Fantail flew low into the nest-tree and ascended to the nest. On 15 November, the female visited the nest, fed the nestling and then flew $60 \mathrm{~m}$ from the nest and mobbed another potential nest-predator, a Crinkle-collared Manucode Manucodia chalybatus (Paradisaeidae). Nest-defence behaviour by both male and female Fantails toward the Manucode was similar to that described for the Catbird.

\section{Discussion}

\section{Breeding season}

Records of Black Fantail nesting include a nest and egg collected in early January near Mt Simpson, far southeastern New Guinea (Harrison \& Frith 1970); active nests at Efogi, Owen Stanley Range, south-eastern New Guinea, in November (Filewood 1967), at Mt Kaindi, near Wau in October (Filewood 1974), and near Mt Giluwe, Central Ranges, in late May (Close et al. 1982); and my observations of nesting in the Arfak Mountains in November. These all indicate breeding in the late dry and early wet season, and the late wet-early dry season.

\section{Nest, nest-site and clutch-size}

As far as is known, the Black Fantail's cup-shaped nest with a 'tail' composed of fibrous plant material bound with spider web is typical of all Australasian rhipidurids (Coates 1990; Boles 2006; Higgins et al. 2006) with the exception of the Dimorphic Fantail Rhipidura brachyrhynchus, which builds an atypical moss nest without a 'tail' (Donaghey $2015 b)$. Coates (1990, p. 132) stated that the Black Fantail nest "is built low down on a horizontal fork of a thin twig", and Boles (2006) and Pratt \& Beehler (2015) stated that the nest is placed near the ground, but actual heights of nests above the ground are not documented in these references nor by Filewood (1967, 1974), Harrison \& Frith (1970) or Close et al. (1982). The two nests of this species recorded in the present paper $(12.5 \mathrm{~m}$ and $6 \mathrm{~m}$ above the 
ground) indicate that this species also nests high above ground, so nests are built from high up near the canopy of middle-storey trees to the low understorey. This study again found a clutch-size of one.

\section{Incubation behaviour and care of nestling}

My observations of spacing between neighbouring pairs of forest-dwelling Black Fantails suggest territorial socially monogamous pair-breeders in this species even though no intraspecific agonistic interactions were seen in the present study. Both the male and the female of this species share incubation almost equally. There is no information on male and female contributions to incubation in other forestdwelling rhipidurids endemic to New Guinea (Coates 1990; Boles 2006). Among seven Rhipidura species of Australia and New Zealand, both male and female share incubation in the Willie Wagtail $R$. leucophrys, Northern Fantail $R$. rufiventris, Grey Fantail $R$. albiscapa, New Zealand Fantail $R$. fuliginosa and Rufous Fantail $R$. rufifrons (Johnstone \& Storr 2004; Boles 2006; Higgins et al. 2006), but confirmation is lacking for the Mangrove Fantail $R$. phasiana and Arafura Fantail $R$. dryas. There is a paucity of information on care of nestlings in New Guinean fantails, but both the male and the female care for nestlings in the Willie Wagtail (Goodey \& Lill 1993), and Grey, New Zealand, and Rufous (Higgins et al. 2006), and Northern, and Mangrove (Johnstone \& Storr 2004) and Arafura (Boles 2006) Fantails. In one of the few studies to quantify male and female contributions to all aspects of parental care in rhipidurids, Goodey \& Lill (1993) found that both male and female Willie Wagtails contributed equally to most aspects of care of nestlings. This pattern of male investment is consistent with the theory that biparental care of nestlings favours the evolution of social monogamy (Goodey \& Lill 1993). Although much more quantitative data on incubation and brood care, and nest success, in the Black Fantail are needed, my results tentatively suggest the same pattern.

\section{Nest-defence and anti-predator behaviour}

My observations in the Arfak Mountains of a pair of nesting Black Fantails mobbing a Black-eared Catbird and a Crinkle-collared Manucode suggest that these larger birds are potential nest-predators. Frith \& Frith (2004) identified the former as a nest-predator, and Frith \& Beehler (1998) stated that the Glossy-mantled Manucode Manucodia ater is a predator of small passerines. Nesting pairs of Rufous Fantails harass and mob Green Catbirds Ailuroedus crassirostris, and once I saw a Green Catbird take a Rufous Fantail nestling (Donaghey 1981).

\section{Acknowledgements}

Iwein Mauro and Like Wijaya of Papua Expeditions kindly negotiated with Kwau villagers and arranged our accommodation and food. Jeff Skevington supplied campsite co-ordinates. My late mother Mrs E. Donaghey financed our trip to West Papua Province. Carolyn Donaghey provided support and helped with fieldwork, which was inspired by the wonderful endemic birds-of-paradise, bowerbirds and robins of the Arfak Mountains, the splendid books on New Guinea birds written and published by Brian Coates, and books by Cliff Frith and Dawn Frith (bowerbirds), Cliff Frith and Bruce Beehler (birds-of-paradise) and Bruce Beehler and Thane Pratt (birds of New Guinea). Cliff Frith's and Guy Dutson's constructive comments improved the manuscript.

\section{References}

Beehler, B.M. \& Pratt, T.K. (2016). Birds of New Guinea: Distribution, Taxonomy, and Systematics. Princeton University Press, Princeton, New Jersey, USA.

Boles, W.E. (2006). Family Rhipiduridae (fantails). In: del Hoyo, J., Elliot, A. \& Christie, D.A. (Eds). Handbook of the Birds of the World, Volume 11: Old World Flycatchers to Old World Warblers, pp. 200-242. Lynx Edicions, Barcelona, Spain.

Close, D., Close, E., Loyn, R. \& Teese, D. (1982). The Siwi Utame Wildlife Management Area. Papua New Guinea Bird Society Newsletter 193-194, 32-36.

Coates, B.J. (1990). The Birds of Papua New Guinea, Volume II: Passerines. Dove Publications, Brisbane.

Croxall, J.P. (1977). Feeding behaviour and ecology of New Guinea rainforest insectivorous passerines. Ibis 119, 113-146.

Donaghey, R.H. (1981). The Ecology and Evolution of Bowerbird Mating Systems. PhD thesis, Monash University, Melbourne.

Donaghey, R.H. (2015a). Incubation behaviour and parental care of a nestling in the Black Monarch Symposiarchus axillaris. Australian Field Ornithology 32, 87-97.

Donaghey, R.H. (2015b). Nest and egg of the Dimorphic Fantail Rhipidura brachyrhyncha and a review of clutch-sizes in New Guinean passerines. Australian Field Ornithology 32, 69-86.

Filewood, L.W. (1967). Observations (Efogi). New Guinea Bird Society Newsletter 26, 3 .

Filewood, L.W. (1974). Preliminary list of species observed 1973 RAOU congress/campout. New Guinea Bird Society Newsletter 94 (Supplement), 1-10.

Frith, C.B. \& Beehler, B.M. (1998). The Birds of Paradise: Paradisaeidae. Oxford University Press, Oxford, UK.

Frith, C.B. \& Frith, D.W. (1993). Results of a preliminary highland bird banding study at Tari Gap, Southern Highlands, Papua New Guinea. Corella 17, 5-21.

Frith, C.B. \& Frith, D.W. (2004). The Bowerbirds: Ptilonorhynchidae. Oxford University Press, Oxford, UK.

Gill, F. \& Donsker, D. (Eds) (2017). IOC World Bird List (v. 7.1). Available online: http://www.worldbirdnames.org (retrieved 11 January 2017).

Goodey, W. \& Lill, A. (1993). Parental care by the Willie Wagtail in Southern Victoria. Emu 93, 180-187.

Harrison, C.J.O. \& Frith, C.B. (1970). Nest and eggs of some New Guinea birds. Emu 70, 173-178.

Higgins, P.J., Peter, J.M. \& Cowling, S.J. (Eds) (2006). Handbook of Australian, New Zealand \& Antarctic Birds, Volume 7: Boatbill to Starlings. Oxford University Press, Melbourne.

Irestedt, M., Fuchs, J., Jønsson, K.A., Ohlson, J.I., Pasquet, E. \& Ericson, P.G.P. (2008). The taxonomic affinity of the enigmatic Lamprolia victoriae (Aves: Passeriformes) - An example of avian dispersal between New Guinea and Fiji over Miocene intermittent land bridges? Molecular Phylogenetics and Evolution 48, 1218-1222.

Johnstone, R.E. \& Storr, G.M. (2004). Handbook of Western Australian Birds, Volume II: Passerines (Blue-winged Pitta to Goldfinch). Western Australian Museum, Perth.

Nyári, Á.S., Benz, B.W., Jønsson, K.A., Fjeldså, J. \& Moyle, R.G. (2009). Phylogenetic relationships of fantails (Aves: Rhipiduridae). Zoologica Scripta 38, 553-561.

Pratt, T.K. (1982). Additions to the avifauna of the Adelbert Range, Papua New Guinea. Emu 82, 117-125.

Pratt, T.K. \& Beehler, B.M. (2015). Birds of New Guinea. 2nd edn. Princeton University Press, Princeton, New Jersey, USA.

Sánchez-González, L.A. \& Moyle, R.G. (2011). Molecular systematics and species limits in the Philippine fantails (Aves: Rhipidura). Molecular Phylogenetics and Evolution 61, 290-299.

Winkler, D.W., Billerman, S.M. \& Lovette, I.J. (2015). Bird Families of the World: An Invitation to the Spectacular Diversity of Birds. Lynx Edicions, Barcelona, Spain.

Received 30 January 2017, accepted 7 March 2017, published online 31 May 2017 